\title{
EL AMANTE Y EL HÉROE EN GARCILASO DE LA VEGA (1933) DE MANUEL ALTOLAGUIRRE
}

\begin{abstract}
Hay un tipo de literatura corriente (biografía, recuerdo, anécdota, etc.) que no tiene interés o tiene poco interés cuando el que la escribe, por bien que la escriba, escribe sólo eso. Pero esa "escritura" acompaña de un modo encantador la obra de quien tiene Obra, porque en ella es donde está visible el escritor, que en la Obra es secundario, o, mejor dicho, está absorbido.
\end{abstract}

J.R. JIMÉNEz, Estética y ética estética

Manuel Altolaguirre fue un lector constante de la obra de Garcilaso de la Vega. De ese vivo interés, hay diversas pruebas. Y la consideración de esas pruebas supone la revisión de casi todas las actividades literarias que el malagueño desarrolló a lo largo de su vida. Hablar del vínculo entre la obra de Altolaguirre y la poesía de Garcilaso implica recorrer su obra poética, su crítica literaria, la escritura de una casi olvidada biografía, el estudio de sus ideas acerca de la historia de España y la revisión de algunas de las ediciones que salieron de sus famosas imprentas ${ }^{1}$. El

${ }^{1}$ Fue en las páginas de la revista 1616 en donde Altolaguirre editó por primera vez algunos poemas de Garcilaso. Esta revista, una de las más hermosas que publicó por sus vivos colores y por su inmejorable composición tipográfica, llevó ese título, 1616, en recuerdo del año de la muerte de dos cumbres de la literatura: Cervantes y Shakespeare. Fue una revista bilingüe publicada en Londres entre los años 1934 y 1935. Fue en 1939, ya en el exilio en Cuba, cuando Altolaguirre preparó una edición de la Égloga primera y de la Égloga tercera. Dicha edición formó parte de la colección El Ciervo Herido. En México, el malagueño hizo una edición mucho más amplia de la obra de Garcilaso. Bajo el título de Poesías, y en el siguiente orden, reunió las tres églogas, las dos elegías, la epístola a Juan Boscán, las cinco canciones, treinta y ocho sonetos y siete breves canciones. Es decir, Altolaguirre sólo omitió las poesías latinas de Garcilaso, los sonetos de dudosa atribución (";Oh celos 
texto en que con mayor amplitud Altolaguirre estudió la vida y la obra del toledano es una biografía: Garcilaso de la Vega (1933)². Este libro aparece en un momento muy oportuno: apenas tres años antes de la conmemoración del aniversario de la muerte de Garcilaso de la Vega (el toledano murió aparentemente en 1536). Así como los poetas del 27, en plena efervescencia de las vanguardias, homenajearon en Góngora al gran renovador de la poesía, Garcilaso pudo haber sido un motivo ideal para ahondar en la rehumanización del arte. Por aquella época, los jóvenes poetas volvían a usar las estrofas clásicas y a frecuentar algunos de los temas desplazados por las vanguardias.

Es cierto que Garcilaso hizo acto de presencia por aquellos años en sus obras e incluso antes. Recordemos el antecedente de Égloga, Elegía, Oda de Cernuda (1927-1928); y también La voz a ti debida (1933) de Pedro Salinas. En el primero de los casos, tenemos una interesante reinterpretación del clasicismo español; en el segundo, un poemario que crea y propone un nuevo lenguaje para el amor; sin embargo, dicho lenguaje se alimenta de la poética garcilasiana. Es necesario decir, no obstante, que los festejos por los 400 años de la muerte de Garcilaso pasaron casi desapercibidos, sobre todo porque 1936 fue el año en que comenzó la Guerra Civil. Las prioridades habían cambiado. Curiosamente, 1836 también fue un año muy importante para la literatura española y, en especial, para el Romanticismo: en aquel año nacía Gustavo Adolfo Bécquer.

Antes de analizar algunas de las características de este libro primordial en la obra de Manuel Altolaguirre, vale la pena señalar un par de elementos en torno al resurgimiento del género biográfico en Europa y, particularmente, en España, toda vez que el libro que aquí se estudiará es, sin duda, el resultado de dicho fenómeno editorial. A lo largo de los años veinte, treinta y cuarenta, las casas editoriales en España mostraron un verdadero interés por publicar libros que recreasen las vidas de los hombres

de amor, terrible freno!" y "El mal ha hecho en mí su cimiento"), y algunos sonetos que, a su vez, Tomás Navarro Tomás no incluyó en su primera edición de la poesía del toledano. Véase también Garcilaso de la Vega, Poesías, Isla, México, 1945 (Col. Los clásicos). En el colofón, se lee lo siguiente: "Este libro se terminó de imprimir en la séptima imprenta de Manuel Altolaguirre el 18 de agosto de 1945 en la Ciudad de México".

2 Manuel Altolaguirre, Garcilaso de la Vega, Espasa-Calpe, Madrid, 1933 (Vidas Extraordinarias, 10). Toda cita que se haga de la biografía será de esta edición. 
y de las mujeres del siglo XIX. Al principio, los editores españoles hallaron en los catálogos de otros países europeos una generosa fuente de materiales. Pero, al mismo tiempo, los autores consagrados, así como también los nuevos, impulsados por esa efervescencia literaria, emprendieron la escritura de obras propias. En muchos de los casos el factor común de los personajes que escogieron para sus biografías fue su filiación con el Romanticismo, ya fuera ésta verdadera o sólo aparente. En gran medida, esta preferencia por el siglo XIX se debió al interés revisionista de José Ortega y Gasset. Garcilaso de la Vega se incluyó precisamente en la colección Vidas Extraordinarias, la cual fue promovida por el filósofo. Los personajes de esta colección comparten, y para notarlo bastaría repasar rápidamente los títulos de los volúmenes, un común denominador: son hombres y mujeres cuyas existencias resultan de interés sobre todo por aquellos elementos pasionales que las caracterizan, es decir, por la fuerza que dichos personajes imprimen en sus actos, por la forma en que viven, según sea el caso, el amor o el poder.

Ana Rodríguez-Fisher estudió precisamente la influencia de Ortega y Gasset en este resurgimiento del género biográfico en España; en particular, la decisión de concentrarse en un período histórico determinado: "Era necesario volverse hacia ese siglo, examinarlo e intentar rescatar lo común y cotidiano estéticamente salvados, asumir el pasado inmediato, para mejor comprender el presente y trazar así la línea de continuidad entre ambos momentos históricos..."3. La misma investigadora ha descrito la manera en que aparecieron algunas biografías de autores extranjeros y el proceso que aconteció en España:

Tras la difusión y el éxito que en nuestro país alcanzaron los trabajos de Lytton Strachy, André Maurois, Stefan Zweig o Emil Ludwig - por citar ejemplos significativos de distintas tradiciones-, se fortalece la curiosidad e interés por este género que en España contaba ya con un precedente: la efímera colección de biografías publicada en 1915 por la editorial de la Residencia de Estudiantes, que divulgó varios modelos más o menos clásicos, pues pertenecían a la etapa anterior al moderno auge del género. A esta temprana iniciativa le seguirían otras, en gran medida resultado de la atención prestada a los biógrafos por destacados críticos

3 Ana Rodríguez-Fisher, "Un proyecto de Ortega y Gasset: la colección Vidas Españolas e Hispanoamericanas del siglo XIX”, Scriptura, Lleida, 1991, núms. 6/7, p. 135. 
-Marichalar, Baeza y Díez-Canedo, entre otros- o del ejemplo que suponía la arriesgada e innovadora colección "Efigies", de Ramón Gómez de la Serna ${ }^{4}$.

La publicación de textos de este tipo en la Península -en particular aquellos que aparecieron en la colección dirigida por Ortega y Gasset: Vidas Españolas- puede enmarcarse dentro de la llamada tendencia neorromántica de la época. Leo Geist ha visto en la efervescencia del género biográfico un signo de los tiempos:

La intensa politización del ambiente forma parte de lo que buen número de críticos dio en llamar en la época "nuevo romanticismo" o "neorromanticismo", identificando así el movimiento coetáneo con el siglo pasado. Efectivamente, hacia 1930 se evidencia un renovado interés en los personajes y el arte del movimiento romántico. Los mejores prosistas de la generación -Antonio Espina, Benjamín Jarnés- colaboraron en la serie de "Vidas Ilustres Españolas e Hispanoamericanas del siglo XIX" (casi todas figuras románticas), que editó Espasa-Calpe a partir de 1929. El interés por Bécquer va en aumento. En 1935 se celebró con entusiasmo el centenario del romanticismo español ${ }^{5}$.

Desconcertante resulta que Geist no incluya a Altolaguirre entre los "mejores prosistas" del 27, sobre todo porque su Garcilaso de la Vega para nada desmerece frente a los libros escritos por Espina y Jarnés (aunque es verdad que el malagueño no fue novelista como sí lo fueron los otros dos autores). De hecho, a pesar del trabajo que le costó incorporar los materiales históricos en su texto, y de la gran inseguridad que padeció durante el proceso de escritura, la biografía de Altolaguirre resulta, casi setenta años después, mucho más legible, fresca y apreciable que, por ejemplo, el Luis Candelas (1930) de Antonio Espina, una obra que parece responder a intereses comerciales más que a inquietudes estéticas ${ }^{6}$.

4 Ana Rodríguez-Fisher, "Manuel Altolaguirre en su Obra Completa", Íns, 1992, núm. 541, p. 7.

${ }^{5}$ LEO GEIST, La poética de la generación del 27 y las revistas literarias: de la vanguardia al compromiso. 1918-1936, Labor-Guadarrama, Barcelona, 1980, p. 193.

${ }^{6}$ Acerca de este fenómeno, vale la pena consultar la muy interesante y completa investigación de EnriQue Serrano Asenjo, Vidas oblicuas. Aspectos teóricos de la biografía en España (1928-1936), Universidad, Zaragoza, 2002. 
Garcilaso de la Vega, tal como lo señaló el editor de las Obras completas de Altolaguirre, James Valender, es el mayor logro prosístico del malagueño. La lectura de la biografía es muy enriquecedora, porque en sus páginas el autor no sólo se encarga de comentar asuntos que están relacionados con Garcilaso y sus versos, sino que también, de forma complementaria, ofrece allí su visión acerca de temas variados como lo serían la poesía, la política, el arte, el heroísmo, el Romanticismo, la España del siglo xvi y la España del siglo xx, etc. El estudio que Altolaguirre hace de la vida del toledano lo lleva, a final de cuentas, a articular su propia visión del arte y de la vida. Por ello, resulta extraña la poca atención crítica que el libro ha recibido a lo largo de los años.

En Garcilaso de la Vega, el poeta moderno va en pos del poeta de la España del siglo XVI. Una de las primeras y más grandes dificultades que enfrenta el biógrafo se le presenta cuando intenta determinar la naturaleza de Garcilaso. Las definiciones son inoperantes y la única manera en que puede hablar del poeta es usando una mirada entonces netamente poética:

Garcilaso no es un poeta, es un perfume que no se percibe por el olfato, es una dura sustancia espiritual que produce emanaciones, es una fuente inextinguible de poesía. Mejor dicho, no es una fuente. Es algo más. La fuente deja brotar un hilo o caño que corre por un cauce y lo que brota del solo nombre de Garcilaso es algo más. Ya he dicho perfume, pero no es exacto. Seríalo más si dijera un perfume percibido por la vista. Esto es, un continuo desprendimiento de formas, de imágenes, de sueños (p. 17).

El camino de las definiciones es una senda fallida. Hay un rasgo, empero, que resulta indispensable señalar, el cual pareciera describir mejor que cualquier otro la imagen que Altolaguirre propone de Garcilaso de la Vega, tanto de su vida como de su obra, en las páginas de la biografía. Dicho elemento es uno de los ejes de toda la producción poética del autor de Las islas invitadas. Me refiero a la interioridad. Para Altolaguirre, todos los sucesos realmente importantes de la vida de un hombre transcurren siempre adentro: "La vida pública de Garcilaso de la Vega no podemos considerarla dolorosa. Su dolor lo llevaba dentro, su verdadera vida fue vida interior" (p. 13). Muchas veces el biógrafo insiste en ello en las páginas de la biografía. De hecho, Altolaguirre se propuso retratar literariamente el mundo interior del poeta. Si consideró su "vida exterior", solamente lo hizo con la 
intención de contrastar esos dos ámbitos, tal y como lo ilustra la cita anterior. Este tema, lo exterior en contraposición con lo interior, aparece con constancia en la obra de Altolaguirre. Sin embargo, Altolaguirre tiene necesariamente que narrar e imaginar los episodios y las aventuras de este caballero español. Para ello, utilizará libremente los datos archiconocidos de la vida del poeta y usará, en muchos de los casos, los versos de Garcilaso con la intención de ilustrar e imaginar su vida. Es curioso, por cierto, que los reseñistas de la biografía no hayan realmente criticado ni reparado en esa libertad con que Altolaguirre imaginó la vida del toledano ${ }^{7}$. Esto nos habla precisamente de la libertad con que podían proceder los biógrafos del momento: las biografías eran un entretenimiento como lo podían ser, desde luego, los textos novelísticos, un espacio propicio para la imaginación. La investigación que hizo Altolaguirre fue rigurosa, a pesar de los apremios, en la medida en que sí consultó diversos textos históricos y biografías escritas por otros autores; sin embargo, su interpretación de los materiales es libérrima. Por ejemplo, llama la atención el modo en que lee y utiliza la Vida del célebre poeta Garcilaso de la Vega (1850), obra escrita por Fernández de Navarrete y una de sus fuentes principales.

Son muchos los aspectos de Garcilaso de la Vega que merecen ser estudiados y atendidos. En las siguientes páginas sencillamente me limito a analizar el modo en que Altolaguirre dibuja al toledano como amante y como héroe.

\section{El amante}

Por medio del recuento de los supuestos amores del toledano, Altolaguirre construye una visión contradictoria del poeta. Haciendo libre uso de su imaginación, a la vez que de los poemas bucólicos de Garcilaso, el biógrafo oscila entre presentar al personaje como un perfecto neoplatónico y describirlo como un

${ }^{7}$ Las reseñas del libro fueron, en su mayoría, implacables. Éstas son las principales reseñas que aparecieron: Guillermo DE TORRE, reseña de Eduardo Ontañón, El cura Merino y de Manuel Altolaguirre, Garcilaso de la Vega, Luz, Madrid, 21 diciembre de 1933, p. 10; J.M.A., reseña de Garcilaso de la Vega, El Sol, 9 de diciembre de 1933, p. 4; José María Salaverría, "El más gentil poeta", $A B C$, Madrid, 6 diciembre de 1933, pp. 1-2; y RAMón SÉnder, "Garcilaso y el Danubio azul", La Libertad, Madrid, 3 diciembre de 1933, p. 8. 
amante capaz de gozar libremente ${ }^{8}$. Es decir, su presentación de lo neoplatónico no es congruente con lo que implica, en su pureza extrema, esa famosa escuela. Además, las aventuras amorosas del poeta tienen un tinte claramente romántico. Algunos pasajes de la biografía permiten relacionar el libro de Altolaguirre con uno de los planteamientos clásicos de esa otra archiconocida escuela: los personajes románticos por excelencia nunca sabrán lo que significa la superación del deseo. El mundo es un teatro para la insatisfacción y para anhelos infinitos. Aunque el conflicto entre "realidad" y "deseo" es moderno, Altolaguirre lo utiliza con frecuencia en una biografía que retrata a un hombre del siglo XVI. Por ello, resulta inadecuado analizar de forma unidimensional el amor en esta obra: una concepción renacentista, como lo sería el Neoplatonismo, se mezcla con preceptos provenientes del Romanticismo ${ }^{9}$.

A lo largo de los siglos, los lectores y estudiosos de la poesía de Garcilaso han querido descifrar la identidad de los amo-

${ }^{8}$ Recuérdese lo que en las páginas de El cortesano se recomienda acerca del comportamiento del caballero enamorado y sus limitaciones: “...tenga licencia de hacer todas las demostraciones de amor a quien lo amare, salvo aquellas que podrían dar esperanza de cosas deshonestas" (BALTasar CAsTiglione, El Cortesano, trad. Juan Boscán, introd. Marcelino Menéndez y Pelayo, CSIC, Madrid, 1942, p. 290).

9 Indudablemente, la poesía de Garcilaso es un testimonio de la sensibilidad neoplatónica y renacentista. Claro ejemplo de ello es el soneto "Escrito está en mi alma vuestro gesto". Allí el poeta anota que la belleza de la mujer trasciende lo meramente físico, lo propiamente sensual; es decir, se trata de una concepción intelectual y espiritual del amor y, por tanto, de una experiencia que rebasa lo meramente carnal. Como lo ilustra esta composición, la mujer se ha transformado en escritura y la hoja de papel es, de acuerdo con lo asentado por Garcilaso, el alma del poeta; allí se asienta la dama que provoca e inspira el amor. Entre los diversos estudiosos que han investigado la manera en que el toledano incorpora los elementos esenciales de la doctrina neoplatónica en su poesía, conviene recordar el nombre de ALEXANDER PARKER. Este investigador observa que si bien la primera etapa de la poesía de Garcilaso corresponde todavía con la estética del cancionero, sus poemas posteriores muestran, por una parte, el mundo clásico y pastoril y, por el otro, esa sofisticada filosofía del amor que es el Neoplatonismo: “Garcilaso's later poetry is Italianate in its Neoplatonic content as well as in its form, but the content of his early poetry still represents the cancionero tradition" (The philosophy of love in Spanish literature, 1480-1680, Edinburgh University Press, Edinburgh, 1985, p. 44). En su libro, Parker señala, al analizar algunas de las canciones y de las églogas del toledano, que la concepción neoplatónica del amor implicaba usar la razón para combatir el sufrimiento por el desengaño; sin embargo, el sufrimiento persiste tal y como ocurre en la Égloga III. 
res del poeta. Cabe señalar que son recurrentes algunas hipótesis acerca de los amores de Garcilaso de la Vega. Los textos a los que los eruditos han acudido frecuentemente con este fin son, desde el siglo Xvi, las églogas del toledano. Una de las dos grandes hipótesis de esta tradición crítica podría resumirse de este modo: que los pastores de las églogas de Garcilaso, como conjunto de máscaras, dramaticen ciertos asuntos de su vida sentimental, y que así representen pasiones y frustraciones amorosas muy específicas; mientras que los nombres de los pastores - pienso ahora en Nemoroso y Albanio- servirían para esconder la identidad de los hombres y mujeres en cuestión. Por ejemplo, Nemoroso sería la máscara de Boscán, puesto que la traducción de la palabra latina nemus significa "bosque"; Albanio, por su parte, sería el duque de Alba. Sin embargo, la caracterización de Albanio como un pastor enloquecido ha contribuido a que los lectores invaliden esta propuesta, ya que muy difícilmente Garcilaso habría dibujado al duque de Alba como un loco. La otra hipótesis, la que va en sentido contrario, subraya que todos los pastores del mundo poético de Garcilaso son transfiguraciones del poeta y que sus lamentos y gozos recrean, en exclusiva, los del toledano. Esta segunda línea interpretativa es a la que se adscribe Altolaguirre. Por ello, regularmente adapta en su biografía pasajes de los poemas y los utiliza con la finalidad de representar la vida sentimental del poeta de Toledo:

El primer amor de Garcilaso fue un amor campestre, que tomó por modelo en sus futuras composiciones para describir y lamentar sus amores cortesanos. La poesía bucólica de Garcilaso no sólo tuvo su origen en los clásicos que imitó, sino también del género de vida que hizo siendo muchacho. En la Égloga segunda habla Albanio de sus contrariedades amorosas, y este Albanio es Garcilaso, aunque otras opiniones sustenten los comentaristas. Garcilaso, al mismo tiempo que Albanio, es Nemoroso, y al mismo tiempo Salicio y Tirreno, pues en estos personajes desdobló el poeta sus múltiples personalidades. En cada uno de ellos puso una de las grandes pasiones de su vida, tan fuertes y elevadas que unas con otras se confundían, y por tener asiento en la misma alma parecían una sola. De este modo se unificó el amor en un pecho capaz de sentir tantos amores (p. 57).

Más allá de los modelos literarios, más allá de la imitación, más allá de Teócrito y Virgilio, de las consabidas fuentes clásicas, Garcilaso tuvo que nutrirse, según Altolaguirre, de los pro- 
pios hechos de su existencia, de su vida misma. Por esto, el autor se queda con la interpretación de Fernando de Herrera, la cual propugna por ver en cada uno de los pastores una imagen confiable del poeta y de su historial amoroso.

$\mathrm{Al}$ describir la relación entre el poeta y la mítica Isabel de Freyre, el biógrafo aprovecha el contenido de la Égloga primera. El modo en que Altolaguirre lee y comprende el poema bucólico se halla en perfecta sintonía con el tipo de lectura que desarrolla a lo largo del libro, pues defiende la idea de que hay un vínculo directo e indiscutible entre la vida del poeta y sus composiciones: "Las quejas que expresó en su Égloga primera son tan sentidas y profundas que en toda la obra de Garcilaso no hay nada tan hondamente humano" (p. 89) ${ }^{10}$. El poema resulta importante para Altolaguirre, no sólo por la maestría técnica con que el toledano escribe, sino por su humanidad. Azorín valoró la obra de Garcilaso utilizando esa misma categoría cuando habló de él como un “...poeta humano, esencialmente humano, este poeta terrestre, esencialmente terrestre"11.

El primer amor de Garcilaso, según lo sostiene Altolaguirre en su biografía, habría sido su prima. Para construir la narración de esos hechos imaginarios, Altolaguirre se deja guiar por los contenidos de la Égloga segunda, especialmente por los versos en que el poeta cuenta las aventuras de Albanio y Camila, sus paseos

${ }^{10}$ En algunos momentos de la biografía, los poemas del toledano se ajustan mejor a este proceso de adaptación; en otras ocasiones, los versos difícilmente sirven al biógrafo para armar un relato coherente. Y por ello el autor se ve en la necesidad de forzar los contenidos y de hacer una selección muy particular de los pasajes que copia y glosa. En la última parte del libro, en el capítulo intitulado "Las ninfas", se aclaran los alcances del método seguido por Altolaguirre, especialmente los defectos. Hay que decir, además, que en esa sección de Garcilaso de la Vega el malagueño mezcla lo real con lo irreal, apoyándose para ello en un sueño que habría tenido el poeta. Aquí el texto reinterpretado es el pasaje en que el toledano hace un recuento de las imágenes mitológicas plasmadas por las ninfas en las telas que estaban tejiendo. En un pasaje de la biografía, Garcilaso se transforma, sin más ni más, en Apolo: "Garcilaso, evocando, vivió muchas horas de su vida. Vio nacer de un río paternal y de la madre tierra a Dafne, tan hermosa que más huía para no entregarse. Garcilaso la vio sólo un momento, ya que cuando quiso hacerla suya, ella encontró en su madre una defensa. De corcho duro revistió sus miembros. Sus cabellos que al oro obscurecían se hicieron hojas y sus brazos ramas. Verdores fue todo su ser desnudo. Madera dura el pecho. Los pies se le enterraron y en torcidas raíces se volvieron" (p. 194).

11 Azorín, "Garcilaso", Al margen de los clásicos [1915], recogido en Obras escogidas. Ensayos, ed. M.A. Lozano, Espasa, Madrid, 1998, t. 2, p. 1277. 
y sus juegos por los campos: "Garcilaso con su primera novia recorrió campos soñados y reales, pues su imaginación vio grandes bosques donde no existían, selvas salvajes donde sólo había campos de soledad y de cultivo" (p. 57). Al narrar el momento último de esa relación amorosa, Altolaguirre reescribirá, precisamente, las escenas de dolor y locura de Albanio e, incluso, reutilizará la escena del poema bucólico en que este personaje intenta suicidarse. La causa del fracaso padecido en esa ocasión por el amante y poeta puede parecer, a primera vista, insustancial e indefinible, sobre todo porque Altolaguirre no determina una razón precisa o exacta que justifique, en ese momento de la obra biográfica, la ruptura; sin embargo, el razonamiento de Altolaguirre nos sirve para percibir el personaje como un ser insatisfecho y anhelante. Nada ni nadie puede bastar para él: "No fue Garcilaso afortunado en estos amores y seguramente no porque la muchacha no se le entregara, sino por la naturaleza de su alma, que sentía mayores y más importantes anhelos" (p. 59). En la narración de esta primera relación amorosa, hay rastros evidentes, por un lado, de Neoplatonismo -la pureza absoluta de su vínculo- y, por otro, de un claro Romanticismo -el dramático e impreciso desenlace da cuenta de ello.

La forma en que Garcilaso concibe el amor, según el biógrafo, implica un anhelo que trasciende lo meramente pasional para ir siempre más allá, en busca de lo absoluto. Al describir el primer amor del poeta, Altolaguirre indicó la calidad devastadora de tal experiencia, sobre todo porque aquel acontecimiento insatisfactorio difícilmente habría servido para complacer al poeta, quien buscaba en cada cosa y en cada persona la totalidad. De tal modo que, bajo esta óptica, el amor del poeta sólo puede ser entendido como una manifestación de lo platónico: "Garcilaso aprendió a comprender la belleza corporal para que esta belleza le sirviera de escabel para lograr el disfrute de la belleza absoluta. De los miembros bien proporcionados, de las facciones correctas, de la elegancia de los movimientos, sacó lecciones provechosísimas para la nueva formación de su alma” (p. 82). La experiencia amorosa y la belleza física de la mujer sólo serían, tal como lo indican los neoplatónicos renacentistas, un medio y nunca propiamente un fin. Imposible no pensar, nuevamente, en la obra poética del malagueño: en sus composiciones la reunión de los amantes, o de las personas, sólo es una excusa para el reencuentro del poeta consigo mismo. Por momentos, la actitud del personaje de la biografía, su incapacidad para amar a alguien en 
específico, pareciera corresponder con un tema importante de la poesía de Altolaguirre: la "ceguera amorosa". En varios momentos del libro, describe al toledano como un ciego. Éste es un tema central de la poética del autor de Soledades juntas: "Todos me quieren. No puedo / fijarme en nadie. Desfilo / y se me pierden de vista / los semblantes preferidos"12.

Cuando Altolaguirre habla de la naturaleza espiritual de Isabel de Freyre, apunta que "la dama de los pensamientos de Garcilaso no era un ser real, sino un fantasma al que enriquecía continuamente con perfecciones, a medida que iba viviendo" (p. 83). Isabel sería, según lo asienta Altolaguirre, un fantasma y un ser que el poeta iría perfeccionando, tal como lo recomendaba Marsilio Ficino: "El alma del amado se convierte... en un espejo donde reluce la imagen del amado"13. La amada es sencillamente una imagen, un estímulo para el poeta, una presencia que vive adentro de él y que allí se transforma: "Todas las bellezas que veía en el mundo las transmitía al ser interno, a esa creación suya inexistente, pero tan verdadera. Isabel de Freyre vivía en el jardín de su alma, en el castillo de su pecho; se asomaba a las ventanas de su pasión y se veía en las corrientes aguas de sus acciones" (p. 38). La misma persona, Isabel de Freyre, adquiriría para Garcilaso en la biografía un valor distinto del que le daría su marido, Antonio de Fonseca. En tanto que el amor de Garcilaso operaría de tal modo que Isabel fuera transformada y perfeccionada, la pasión prosaica de Antonio de Fonseca sería, en todo caso, un mero desplante vulgar.

Después de presentar con claros indicios de neoplatonismo la relación ideal entre Garcilaso e Isabel, y después de considerar al tercero en discordia, Altolaguirre incorpora en el texto un fragmento que revela una visión que tiende hacia lo romántico y que confiere a su interpretación una ponderable modernidad: "¡Cuán distinta sería la Isabel de Garcilaso a la de don Antonio de Fonseca! ¿Qué duro encuentro entre la realidad y el deseo!" (p. 82). En otro momento de la biografía, Altolaguirre plantea la oposición entre doña Elena, la esposa de Garcilaso, e Isabel de Freyre en los mismos términos cernudianos: realidad y deseo. Si Garcilaso hubiera unido su vida a la de Isabel de Freyre, los espacios ocupados por las mujeres habrían resultado, para el biógra-

12 M. Altolaguirre, "Todos me quieren. No puedo”, Soledades juntas, Plutarco, Madrid, 1931, vv. 1-4. Para el proyecto de sus Poesías completas, Altolaguirre escogió como título para estos versos el de "Ciego de amor".

13 Marsilio Ficino, Comentario al "Banquete" de Platón, ed. A. Ruiz Díaz, Universidad Nacional de Cuyo, Mendoza, 1968, p. 54. 
fo, intercambiables: Elena sería su deseo, en tanto que Isabel sería su realidad. Ahora bien, la elección que hizo Isabel no fue un impedimento para que los amantes pudieran seguir manteniendo, durante una época importante, un vínculo. En esta ocasión, fue el amor, en su faceta más espiritual, o fantasmal, lo que posibilitó su unión:

...fue tan grande su amor, que un leve fantasma, una transparente forma, un ensueño milagroso, se despegó de la mujer esquiva y con paso silencioso se acercó al poeta. No podía abrazarla con su cuerpo ni besarla con labios de carne; pero cuando atravesó los dinteles de su espíritu, unos brazos interiores, que eran como una brisa, y unos labios, que eran como nubes, acogieron aquel recuerdo para siempre. Ésta fue la conquista espiritual que no abandonó nunca. En ella pensaba y para ella vivía. En su alma fecunda creció esta simiente de amor. Toda la cultura de Italia, todo lo que en ella existía, atravesaba los claros ojos de Garcilaso para adorno y prestigio de un huésped tan amado.

Amar es recoger, dar albergue, ofrecer un sitio en el alma. Amar es crear una vida interior, un contacto entrañable, almoroso, profundo (p. 83).

Los brazos de los amantes serán "brazos interiores". La conquista del poeta será, sencillamente, una "conquista espiritual". Las dos últimas líneas de la cita funcionan como perfecta síntesis. El amor verdadero es una actividad interna, la creación de un espacio interior. Solamente lo profundo es relevante.

La descripción que ofrece Altolaguirre de la relación de Garcilaso con Isabel de Freyre hace pensar en un Neoplatonismo que parcialmente se apegaría a los modelos literarios y culturales del Renacimiento. Sin embargo, en la biografía ocurre un quiebre sustancial en la tendencia descrita. Me refiero ahora a lo que Altolaguirre incluye en el capítulo titulado "El sueño". En dicho capítulo, el autor describe la unión de los amantes y el cumplimiento del anhelo fundamental del poeta, lo cual atenta contra la esencia misma del Neoplatonismo: "Una mañana de primavera Isabel fue suya" (p. 124). Uno de los rasgos más sorprendentes de este capítulo es la falta de correspondencia que Altolaguirre señala entre lo que el poeta imaginó en un instante previo y lo que efectivamente presenció y vivió:

Hubiera deseado una naturaleza más violenta, una alteración más solemne. También pensaba que Isabel debía de ser no como 
realmente era, sino como hasta entonces la había imaginado su pasión. Y no fue así. Isabel apareció entre el ramaje no como una libre ninfa mitológica, sino con femenina torpeza, como una dama de Toro, pueblerina, temblorosa. Garcilaso la quiso mucho en aquella hora. Le dio todo su amor. Casi se quedó sin él. Ella no sospechaba nada (p. 124).

La figura de Isabel de Freyre no era la de una ninfa, sino la de una dama que poseía una "femenina torpeza"; y el paisaje desmerecía, en su calidad de escenografía, de aquel que los amantes ameritaban. Lo anterior implica una ruptura: un abandono de la idealización en pos de la experiencia real. Sin embargo, Altolaguirre también señala cómo, después de que Garcilaso perdiera la noción de la realidad, su amada gozó un proceso de transfiguración. Entonces el paisaje se convirtió en algo memorable, en algo que el poeta debía recordar por siempre, en algo atendible. El sitio devino en locus amoenus, en un espacio que simbolizaba la máxima felicidad alcanzable. Es notable que esta metamorfosis implique, a su vez, una pérdida de contacto con la realidad:

Hubo un momento en que logró perder la noción de la realidad, y su amante se le transfiguró. Era la de siempre, la de nunca. Entonces sobrevino el desenlace.

Quieto, veía perderse entre los arbustos, por los recodos de las malezas, el cuerpo de Isabel erguido en la niebla, alto, visto desde el suelo.

El paisaje impresionista contemplado hasta entonces por un poeta distraído se le quedó grabado como si su pupila fuera la de un pintor detallista. Aquella confusión de tonos y de vapores, de halos y perfumes, de nubes casi opacas, se iluminaron de pronto y cada rama, cada hoja, cada perfil quedó preciso; cada tono, aislado; cada forma, definiéndose con una fuerza afirmativa.

Estaba tendido junto a las márgenes del río, no solicitado por ninguna pena de las muchas que con frecuencia le visitaban, deshabitada el alma de tantos huéspedes crueles como siempre había tenido, saciado de amor bajo los sauces, en hierbas tálamo, en vegetal celeste luminosa euforia (p. 124).

Por un breve momento, por un solo instante, el personaje encuentra la felicidad. Cuando se halla tendido al lado del río, después de haber gozado el amor carnal de Isabel de Freyre, experimenta el instante de mayor alegría de toda su vida: 
Aquello era la felicidad. Veía claro. La estaba viendo. Le hubiera gustado decirle: Isabel, no te muevas, quédate exactamente ahí, bajo el vuelo de esa avecilla de plumaje tan miniado, junto a la margarita de polen tan esponjoso y exacto, entre rotundeces y afirmaciones de árboles. Mi amor eres tú. Te limitan al norte, al oriente y al ocaso los aires más límpidos. Al sur te limita tu alma, tan profunda, que sus confines interiores son insospechados. Te quiero así, definida y misteriosa, guardadora y al fin entregada.

Aquella fue la única vez que Garcilaso consiguió el amor de Isabel de Freyre, cuando menos esperaba ser correspondido. Después de aquella felicidad sintió un gran vacío, una gran plenitud. Durmió con el agua, junto a la corriente. Su sueño siguió su curso hasta un mar más lejano que el de Lisboa. Más oscuro. Discurría (p. 125).

En aquel momento, el anhelo mayor del poeta era, según Altolaguirre, fijar el instante, congelar el momento, atesorar lo vivido. El biógrafo sugiere, incluso, las palabras que el toledano hubiera querido dirigir entonces a su amada. Por medio de los puntos cardinales, el poeta le hubiera podido señalar sus límites, sus fronteras. Sin embargo, cuando habla del espíritu de la mujer -uno de los puntos de referencia que le servirían para marcar sus límites- dirá que los "confines de su alma" son "insospechados". Del mismo modo, podrá presentar su naturaleza como una entidad en esencia paradójica y contradictoria: "Te quiero así, definida y misteriosa, guardadora y al fin entregada”. Después de que el toledano rompió la norma principal de todo amor que siga los preceptos básicos del Neoplatonismo, encontramos aquí una clara vuelta a la sensibilidad romántica. Si bien aquellos momentos que Garcilaso había compartido con Isabel de Freyre serían los de mayor felicidad y plenitud en su vida, tras esa experiencia lo único que sobreviene es una insatisfacción aun mayor. Experimenta lo mismo un enorme vacío que una gran plenitud. En otro momento de la biografía, Altolaguirre retomará la idea del vacío como consecuencia de una pasión sentimental: "Se te va tu alma hacia Isabel y estás «fuera de ti» como has repetido tantas veces, y estar fuera de sí es la muerte. Yo lo sé, Garcilaso. Yo también conozco ese vacío" (p. 147). Estar afuera es la peor de las penas que el amante puede, como resultado de su infortunio, sufrir.

Después del encuentro con Isabel, Garcilaso sufrirá una pesadilla. El biógrafo señala que en aquel sueño se combinaban elementos pertenecientes a la imaginación del poeta con imágenes provocadas por la angustia. En estos términos presenta el conte- 
nido del sueño: "Inventó en el sueño bajeles, saqueos, bosques, playas. Sobre un fondo azul veía la rosada blancura del cuerpo de su amante, un cuerpo altísimo doblado para recoger el pliegue de un paño imaginario. Unas veces era este cuerpo el que estaba ante el fondo azul de cielo y mar; pero a veces la figura gigante representaba una fiera. Una dulce leona que pastaba o una temible hormiga guerreando" (p. 125). Lo que prima sobre todo en la narración del sueño es la pérdida de las proporciones: "Todo inmenso, todo desproporcionado" (p. 126). Los elementos de la naturaleza también juegan un papel importante en el sueño como fuerzas peligrosas e incontrolables: "El fuego era más violento que en la vida, el viento más compacto y dibujado que en la vida, el agua más desunida, más en lucha contra sí, más loca" $(i d$.$) . Aquella naturaleza era una "naturaleza sentida". Aho-$ ra bien, ¿qué propósito tiene en el capítulo "El sueño" la narración de esta pesadilla? Creo que la respuesta está contenida en estas palabras: "Un sueño duro bien distante de la suave realidad del remanso. Un sueño que angustió al poeta. Se despertó cuando le rodeaban las aves, los rebaños, los peces. Estaba en la vida entre cánticos, hálitos, huidas" (p. 125). En tanto que el lugar donde reposaba el poeta, "el remanso", ofrecía la comodidad y el descanso necesarios, el sueño es una revelación del estado en que se encontraban su alma y su amor. La vuelta a la realidad es inexorable. De hecho, el sueño sirve como epílogo de su relación con Isabel: "No encontró su caballo. Su amante pensaría en él. Decidió no ver más a Isabel de Freyre" $(i d$.$) . La decisión del poe-$ ta deja de ser sorprendente si se considera su compleja caracterización. Lo que durante gran parte de la biografía habría parecido un imposible -que Garcilaso fuera capaz de superar y olvidar el amor que sentía por Isabel- el poeta lo logra tras haber gozado, en aquella ocasión, de la amada:

Estaba tranquilo porque tenía olvidada a Isabel de Freyre desde su último viaje a España. El amor de Garcilaso tomó desde entonces un sentido diferente. Quien vivió atormentado soñando un ideal maravilloso pudo comprobar cuán fácilmente se derribaban los ensueños. Garcilaso, en Toledo, como hemos visto, logró conquistar el amor y los favores de Isabel, que entregó la pobre realidad suya a quien la había soñado tan llena de perfecciones.

La conducta de Isabel ante las locuras de su amante estuvo llena de comprensión y ternura. Quiso abrirle los ojos y fue cruel siendo bondadosa. Al entregarse se negaba para siempre. Ya no 
existía el sueño del poeta; únicamente un recuerdo de carne dada, ajena, sin misterio (p. 156).

El pasaje es bastante claro. Si Garcilaso dejó de amar a Isabel de Freyre, según Altolaguirre, fue por haberla poseído (Isabel le había quitado el vendaje que le impedía ver las cosas como en realidad eran). En la medida en que habían violado el principio esencial de una conducta apegada a las doctrinas del Neoplatonismo, el poeta habría caído en la cuenta de que la experiencia verdadera, los momentos en que estuvo en compañía de Isabel, resultaban poco o nada trascendentales. Isabel le habría dado al poeta, como ofrenda, su "pobre realidad". Esa "pobre realidad" no era nada en comparación con lo que, por medio de la idealización, Garcilaso habría presentido. El conocimiento de la mujer, de su "carne dada", tendría como efecto la consecuente falta de interés. Es admirable, además, la reacción, según Altolaguirre, de Isabel de Freyre: comprensión y aceptación ante el carácter voluble de Garcilaso. Como complemento de lo anterior, el autor de la biografía incluirá una devastadora reflexión acerca del valor de las experiencias sensuales: "Todavía a veces en la soledad encontraba materiales para construir el edificio de su engañosa pasión; pero siempre la cruel verdad le recordaba los momentos vulgares de una correspondencia erótica que no le satisfizo según la medida de sus deseos” (p. 156). Es necesario sopesar los adjetivos de la cita: "engañosa pasión" y "momentos vulgares". En otros pasajes de la biografía, Altolaguirre acepta que Garcilaso mantuvo otras aventuras eróticas, eso sí, "contra su voluntad" (p. 179).

La muerte de Isabel de Freyre, como consecuencia de un parto, hizo que el poeta la recordara de nueva cuenta. El biógrafo entrevé la posibilidad de que puedan reunirse más allá de esta vida: "En este último paisaje deseado, en esos otros llanos y otros ríos, que tan gran prueba ofrecen de la conciencia religiosa del poeta, estarán Garcilaso e Isabel en un idilio eterno, con un amor sin límites" (p. 162). Los "otros montes y otros ríos" 14 de Garcilaso se transforman, en la cita, en "otros llanos y otros ríos". Por lo visto, el amor no tiene cabida en este mundo; sería, pues, no una actividad terrenal, sino ultraterrena, tal como lo plantea Nemoroso en la Égloga primera. Al narrar la relación del pastor

14 Égloga primera, en Poesías castellanas completas, $6^{\text {a }}$ ed., ed. E.L. Rivers, Castalia, Madrid, 1990, v. 403. 
Albanio con Camila, y al describir la desesperación del enamorado, Altolaguirre autoriza, en cierta medida, su buscado suicidio y admite que podrá reunirse con su amada más allá de la muerte: "Quieres vivir, Albanio; quieres morir. Sabes que sólo muriendo has de encontrarte, has de verte libre y por eso buscas tu vida en la muerte. Si te lanzas al agua para recuperar tu cuerpo perseguido lo encontrarás en otra vida, donde por otros valles ignorados irás con Camila para siempre” (p. 175). De nueva cuenta, el amor sólo es posible después de la muerte.

\section{El hÉroe}

Hacia 1930, Juan Chabás llamaba la atención sobre lo siguiente: "La vida de un héroe histórico, escrita con el pie forzado, real, de su existencia fija en los documentos y en los demás varios testimonios, suele, con igual rigor, no alcanzar a ser una buena novela, ni conseguir el valor de lo puramente histórico" 15 . Las líneas anteriores de Chabás indican la dificultad esencial a la que se enfrentaría aquel escritor que quisiera escribir una novela que tuviera por protagonista un héroe histórico, tal como lo es Garcilaso. Si bien el libro de Altolaguirre no es una novela, el malagueño tuvo seguramente que plantearse la cuestión: ¿cómo asociar lo literario con lo histórico? En las páginas anteriores, he analizado la manera en que Altolaguirre recrea al personaje como amante. Es también importante repasar y considerar la forma en que el autor de la biografía describe al toledano en su faceta heroica para, de este modo, atender los componentes básicos del toledano en tanto que caballero. El héroe de Altolaguirre es heroico por ser soldado y por ser poeta. Hay que recalcar que el biógrafo, a la manera de don Quijote de la Mancha, durante el celebérrimo discurso de las Armas y las Letras, no piensa que ambas profesiones sean discordantes. Don Quijote, al finalizar el capítulo 18 de la primera parte, advertía que "...caballero andante hubo en los pasados siglos que así se paraba a hacer un sermón o plática en medio de un campo real como si fuera graduado por la Universidad de París; de donde se infiere que nunca la lanza embotó la pluma, ni la

15 Juan Chabás apud EnriQue Serrano, Vidas oblicuas. Aspectos teóricos de la biografía en España (1928-1936)..., p. 163. 
pluma la lanza"16. Lo que ofrecen las páginas de la biografía es la posibilidad de una síntesis total: que en un solo hombre se congreguen, en plenitud, ambas facetas y que su heroicidad sea el resultado de esa equilibrada y sutil combinación. El poeta y el militar son una sola persona. Lo que motiva sus diversas acciones tiene una sola raíz.

Hay que recordar que la noción de héroe tuvo para Altolaguirre un significado muy especial a lo largo de su vida como creador e impresor. De ello, dan prueba varios poemas que escribió inspirándose en la figura del héroe ${ }^{17}$ y también, desde luego, el título de la revista Héroe (1932-1933), donde colaboró, siempre en la primera página, Juan Ramón Jiménez (bajo el título de "Héroes españoles", el poeta de Moguer publicó allí una serie de retratos de poetas contemporáneos, incluyendo, en primer lugar, al propio Altolaguirre). El hecho de que Altolaguirre haya

${ }^{16}$ Miguel de Cervantes, Don Quijote de la Mancha, Real Academia Española-Asociación de Academias de la Lengua Española, Madrid, 2004, p. 164.

${ }^{17}$ El poema "El héroe" de Manuel Altolaguirre aparece en la revista Poesía en 1931. En el poema, llama la atención la presentación del personaje - del héroe- como un luchador cuya actividad trasciende los hechos armados y deriva en una compleja configuración espiritual del sujeto, tal como ocurre en el texto biográfico. En Garcilaso de la Vega, el escritor presenta al personaje de la biografía como un ser que sufre por lo difícil que le resulta aceptar la realidad tal cual es; incluso llegará a decir que "nunca alma humana se vio tan aislada como la suya de la cruel realidad..." (p. 12). Algo similar ocurre en el poema. El poeta presenta al personaje del poema como un hombre cuyo mundo interno resulta imposible de explorar a cabalidad; sólo somos testigos de su tristeza y de su incomodidad existencial. Detrás de su apariencia externa, en el héroe hay luz y hay fuego; esa poca luminosidad solamente es posible percibirla a través de "barros rotos". Esa misma luz es la que empuja al "héroe". A pesar de ser el vencedor de la batalla, de recorrer el campo donde yacen los cadáveres de sus enemigos, siente todavía miedo y se halla totalmente en soledad; quiere, incluso, la muerte, tal como le ocurre al personaje principal de Garcilaso de la Vega. Una imagen constante del poema es precisamente la cárcel; por tanto, el encierro y el aislamiento. A pesar de tanta muerte, y de esa incapacidad para comunicarse, el orgullo alimenta al héroe: "Y su cadáver vivo, / su prisión pensativa, / victoriosa y sangrante, / orgullosa, se erguía” ("El héroe”, Poesía, Paris, V:7, 1931, vv. 30-33). Años más tarde, en plena Guerra Civil, Altolaguirre escribió un poema que tiene el mismo título. Dicha composición, "El héroe", apareció en el número XII de Hora de España, la célebre revista en que colaboraron los mejores intelectuales fieles a la causa republicana. La composición data de 1937; el tono de los versos es de ánimo y esperanza; el poeta manifiesta en ellos, sin duda, el deseo de mirar hacia delante. 
publicado la revista mientras preparaba su biografía sobre Garcilaso es revelador. Para Jiménez, el término "héroe" tenía una connotación especial. Altolaguirre, a su vez, supo compartir el significado adoptándolo y adaptándolo. Ésta es la definición propuesta por Jiménez en "Héroes españoles": "Llamo héroe a los españoles que en España se dedican más o menos decididamente a disciplinas estéticas o científicas" ${ }^{18}$. El contexto es importante. Según el futuro autor de Animal de fondo, realizar estas actividades con cierta dedicación en España implicaba un esfuerzo heroico por las condiciones adversas. Los poetas, en estos términos, serían indiscutibles héroes. Si bien hay muchas diferencias entre los contextos sociales de los siglos XVI y Xx, el ejercicio de la pluma convirtió a Garcilaso en héroe, tal como lo sugiere la biografía escrita por Altolaguirre, pero no puede olvidarse su faceta de soldado: "Garcilaso de la Vega luchaba fieramente en los jardines con estruendos de aguas, salvas de brisa, deshojando pétalos, devastando un prado, tratando por igual con su heroísmo a la flor y al hombre..." (p. 34). Si bien Garcilaso era un soldado, su espacio de acción iba más allá de los encuentros militares: un jardín -o un poema- podía ser el escenario perfecto para el combate.

Así como las églogas de Garcilaso resultaban para Altolaguirre una fuente apropiada para conocer el historial amoroso del poeta, su obra lírica transparentaría, a su vez, su gran espíritu guerrero: "Su vida y su obra tienen una relación íntima, a pesar de cuanto se ha escrito en contra, pues a través de la más tierna de sus composiciones se trasparenta la fortaleza guerrera de su vida" (p. 11). Para subrayar la heroicidad del personaje, Altolaguirre no duda, incluso, en aprovechar los mitos más disparatados, como aquel combate legendario en que el toledano habría luchado, y salido triunfante, en contra de 300 soldados enemigos, según lo sostuvo Zapata en su poema Carlo Famoso. De este

18 Juan Ramón Jiménez, Antología jeneral en prosa, eds. A. Crespo y P. Gómez Bedate, Biblioteca Nueva, Madrid, 1981, p. 778. Hacia 1932, al sopesar la obra de Juan Ramón Jiménez, y al considerar las dificultades externas que debería enfrentar todo poeta, Luis Cernuda escribió lo siguiente, retomando la idea de lo heroico: “...un poeta es lo excepcional y la sociedad actual no tolera excepciones en su férrea jaula, el poeta, a menos de ser un héroe además, no puede realizar exteriormente la curva que un invisible poder demoníaco parecía haberle asignado" (L. CERnudA, "Unidad y diversidad", en Obra completa. Prosa II, $2^{a}$ ed., eds. D. Harris y L. Maristany, Siruela, Madrid, 2002, t. 2, p. 53). 
modo, el malagueño narra la batalla que supuestamente emprendiera Garcilaso:

Garcilaso empuñó su lanza, fustigó a su caballo y avanzó contra trescientos hombres, que al ver tan temeraria locura no podían comprender lo que les pasaba. No era un hombre, era un ángel con espada de fuego, un jinete sobre oleadas de sol, sobre cristales de nubes; era un devastador castigo. Deslumbrados huyeron, cayendo algunos por la torpeza con que escapan, otros, heridos por los firmes golpes del poeta, que al verse solo con los enemigos en fuga se serenó un momento. Al volver a la realidad, una vez consumado el milagro, divisó a su escudero, que desnudo y apaleado estaba amarrado en una encina. Descabalgó el poeta para desatarlo y luego de curarle sus heridas continuaron su camino hasta llegar a Roma, en donde entregaron los mensajes (p. 214).

Es importante señalar que antes de luchar en contra de esa muchedumbre, según lo dice Altolaguirre en la biografía, el poeta había combatido en la guerra de Túnez -donde fue gravemente herido-y donde también había gozado en el lecho de una anónima cortesana. Tras la guerra, y después de tantos padecimientos físicos y espirituales, "Garcilaso se sentía quebrado por mil partes" (p. 213). Su encuentro con aquella mujer fue un acto de desesperación: "Desesperado fue a refugiarse en el lecho de una cortesana, con la que conversó de sus propósitos. Quería morir. No podía resistir más la vida" (p. 212). Éste es el estado espiritual de Garcilaso antes de entrar en descomunal batalla. La locura no le permitía comprender los sucesos. Según lo expresa el pasaje que narra el combate en contra de los 300 soldados, el toledano no era propiamente un hombre, sino un ser de naturaleza angelical, devastador y justiciero; por medio de esta caracterización -me refiero a la imagen del ángel- confería al poeta y al guerrero un estado superior y el permiso, como si se tratara de un ser bíblico, para ejercer la destrucción. Una observación complementaria: es curioso notar que tras la batalla, según lo asienta el biógrafo, el poeta regresó a la realidad; lo mismo le ocurrió después de haberse unido carnalmente con Isabel de Freyre. El paralelismo es evidente.

Un pasaje de la biografía en que Altolaguirre describe con precisión las aspiraciones del toledano, en tanto que héroe y militar, es el siguiente:

Necesitaba ser fuerte no sólo en ejercicios físicos que le dieran agilidad y resistencia, sino en pruebas morales que elevaran el temple 
de su alma. Quería ser duro, cruel, sanguinario. Clavaba una corneja por las alas para que con sus gritos acudiera otra que, al querer auxiliarla, se dejara apresar por la primera víctima; Garcilaso la cogía, y la cuitada "del bien hecho empezaba a arrepentirse".

Creador creyente, era también un destructor despiadado. Para construir una obra de espíritu destrozaba lo material que admiraba, era enemigo para ser vencedor. Quien cree en la eternidad y crea para ella bien puede acortar la vida de los seres mortales. No podía detenerse a sentir las pequeñas miserias porque era un hombre con sentimientos elevados (p. 23).

La educación que Garcilaso siguió, de acuerdo con Altolaguirre en la biografía, tuvo la finalidad de convertirlo en un hombre fuerte y poco sensible ante el dolor ajeno, sus "sentimientos elevados" se habrían opuesto a la compasión; por ello mismo, el caballero no habría sido capaz, ante la realización de una tarea trascendental, de detenerse y preocuparse por esas "pequeñas miserias"; su misión era todavía más importante que el dolor sufrido por aquellas cornejas. Tanto su cuerpo como su alma debían compartir esa misma fortaleza y esa misma resistencia. Por ello, realizaba actos que daban cuenta de su virilidad y de su crueldad. En esta descripción, hay una frase que resulta demoledora: "Era también un destructor despiadado". Además de tener un don para crear, para escribir sus versos, el Garcilaso de Altolaguirre tenía la autorización para derribar aquello que se interponía entre él y su destino, entre él y su obra inmortal. Esta misma autoridad le consagraba el derecho, según se lee en las líneas anteriores, de matar. Algo parecido a lo que escribió Bécquer en su "Enterramiento de Garcilaso de la Vega y su padre en Toledo" es lo que sostiene Altolaguirre cuando, en la biografía, defiende la idea de que el linaje del toledano lo había preparado para ser tal como fue:

Miembro de una familia aristocrática, de la tradición sacaba los mejores ejemplos de conducta; la tradición completa la memoria, es como una vida más dilatada que se adquiere con el conocimiento de los hechos heroicos de nuestros antepasados. Memoria, inteligencia, voluntad y tradición eran las facultades de su alma. Con ellas llegó a ser el gran héroe español de la poesía (p. 42) ${ }^{19}$.

19 He aquí el pasaje de Bécquer: “¡Oh, qué hermoso sueño de oro su vida! Personificar en sí una época de poesía y combates, nacer grande y noble por la sangre heredada, añadir a los de sus mayores los propios reconocimientos..." ("Enterramiento de Garcilaso de la Vega y su padre en Toledo", Obras completas, ed. J. Estruch Tobilla, Cátedra, Madrid, 2004, p. 828). 
En esta cita, se usa el término "tradición" de una manera que no deja de ser desconcertante por sus implicaciones ideológicas. Empero, hay aquí una prueba, de nuevo, del tipo de fusión que Altolaguirre quería llevar a cabo cuando describe a Garcilaso como "el gran héroe español de la poesía". Otro pasaje que da muy bien cuenta de la fusión que buscaba Altolaguirre es el que ahora transcribo, pero en este caso se amplían y profundizan los atributos de lo propiamente heroico, y se señala la recompensa anhelada: "...la poesía de Garcilaso, con ser tan elevada y espiritual, estaba firmemente unida a sus acciones. Su pasión era activa. Mientras en su alma se desarrollaban los sentimientos más apasionados, sus hechos heroicos le daban esperanzas de conseguir el amor. Quería ser un gran héroe, una figura legendaria, porque esperaba con esto enternecer el corazón de su enemigo" (p. 95).

El poeta es, desde luego, inmortal. Al final del capítulo quinto, Altolaguirre regresa de nuevo al ámbito de las "definiciones poéticas”. En este caso, la reflexión abarca los ámbitos de la poesía y de la heroicidad:

Guerrero y flor era Garcilaso. Los héroes mueren como lirios. La realidad se transforma en poesía. La sangre era savia; los cuerpos, vegetales; los rostros, flores. ¿Cómo llorar la muerte de una rosa? Garcilaso de la Vega luchaba fieramente en los jardines con estruendos de aguas, salvas de brisa, deshojando pétalos, devastando un prado, tratando por igual con su heroísmo a la flor y al hombre, con un corazón enamorado, con la venda de la fe bien mal puesta, volviendo a citar a Juan Ramón Jiménez (p. 34) ${ }^{20}$.

Es éste uno de los pasajes de Garcilaso de la Vega cuyos elementos -por ejemplo, el uso poético del lenguaje y la construcción de imágenes de gran plasticidad- hacen pensar en un género concreto: el poema en prosa. En varios momentos del libro, el biógrafo pareciera ser desplazado por el poeta; y, si su expresión adquiere estos matices, es porque otro uso del lenguaje -directo y sin recursos poéticos- mal funcionaría para describir esas realidades que trascienden lo meramente factual. Por ello, no resulta raro, incluso, que glose un verso de Juan Ramón Jiménez: “Con la venda de la fe bien mal puesta". El verso escogido refuerza una idea que ya antes mencioné: la voluntad que mantiene Altolagui-

${ }^{20}$ El poema que Altolaguirre cita de Juan Ramón Jiménez forma parte de Eternidades: "-¡Lo viste! / -¡Sí, lo veo! / ¡Me pusiste el vendaje / de la fe, con tu prisa, bien mal puesto!" (JuAn Ramón Jiménez, Libros de poesía, $2^{a}$ ed., ed. A. Caballero, Aguilar, Madrid, 1959). 
rre de no presenciar las cosas del mundo sin la intercesión de la fe. En otro momento del libro, después de presentar las dificultades implícitas en el trabajo del biógrafo, utilizando la imagen de un camino nublado por donde debía transitar, Altolaguirre presenta al poeta como un ser angelical:

Un poeta no es un hombre, es un huésped, un ángel, un ser aparte, de otra vida, que habla con labios ajenos. El poeta inmortal casi nunca acompaña hasta la sepultura, muchas veces abandona antes de la vejez, otras veces sólo aparece en la vida de un hombre cuando éste pronuncia una frase o una palabra.

En Garcilaso estuvo hasta que lo mataron. Cuando vio derribada su cárcel, al verse libre de aquel cuerpo heroico no sabía dónde pararse, paseando indeciso por las murallas. El poeta de Garcilaso se asoma ahora muchas veces sobre los hombros de otros jóvenes diciéndoles palabras. Yo lo he visto (p. 103).

Resulta difícil no pensar, tras leer estos renglones, en aquellos famosos versos en que Altolaguirre habla, precisamente, de la naturaleza angelical que sus amigos creían ver en él' ${ }^{21}$. De hecho, es posible sostener que Altolaguirre, al escribir la biografía de Garcilaso, simpatiza tanto con la figura del poeta que incluso se identifica plenamente con éste. O bien, construye una representación arquetípica del Poeta y se funde en ella.

\section{Pablo Muñoz Covarrubias}

UNAM-Acatlán

${ }^{21}$ Al rememorar a Manuel Altolaguirre, Jorge Guillén escribió lo siguiente acerca de la personalidad angelical del malagueño: “Temí que el «ángel» tan ingrávido de Manolito no pudiera resistir el paso de los días, el paso de la edad. No, no... Era todo tan auténtico en aquella criatura que jamás menguó el tesoro juvenil. Una experiencia muy varia enriqueció al ángel y lo hizo más humano" (J. Guillén, "Prólogo a Poesía de Manuel Altolaguirre", Obras en prosa, ed. F.J. Díaz de Castro, Tusquets, Barcelona, 1999, p. 636). Por cierto, esta observación Guillén la dejó afuera de la versión final de su texto; sin embargo, el editor de su Obra en prosa encontró el fragmento aquí citado en la Biblioteca Nacional. Ignoro si pensó o no Guillén en incorporar este pasaje en su prólogo. En esta misma nota marginal, también equipararía a Altolaguirre con García Lorca y hallaría en ambos la encarnación del "ángel” andaluz. Por su parte, Luis Cernuda, en su último poemario, Desolación de la Quimera (1962), también alude a la imagen angelical de Altolaguirre: "Acaso él mismo fuera en parte responsable / Por el afán de parecer un ángel, eterno adolescente" ("Supervivencias tribales en el medio literario", Desolación de la Quimera, $4^{\mathrm{a}}$ ed., ed. L.A. de Villena, Cátedra, Madrid, 1999, vv. 1-2). 
